\title{
MOTIVATION AND THE USE OF TECHNIQUE WITHIN WORKPLACE AND ITS IMPACT ON EMPLOYEE
}

\author{
Asst. Prof. Devyani M. Pihulkar \\ MBA HR and Marketing, M.A. English Literature \\ Department of Management Studies \\ Bapurao Deshmukh College of Engineering, Sewagram, Wardha
}

\begin{abstract}
The purpose of employee motivation is to examine motivation of employees in the workplace to enhance their productivity and increase the work satisfaction through that we can get the satisfactory family life also. Every organization needs to have well motivation in employees to perform their work good in the organization, when the employees have work satisfaction and feel good about their job, certain factor tend to increasing productivity.

Motivation employees that one person, in organization context a manager, includes another, say an employee to engage in action by ensuring that a channel to satisfy those needs and aspiration becomes available to the person. In addition, satisfying to the talent needs in employees and harness them in a manner that would be functional for the organization.
\end{abstract}

Keywords - Employee motivation, productivity, internal and external technique

\section{INTRODUCTION}

Today's lifestyle and globalization leads people to the stressful life. Stressful mind is a unproductive workplace. There are two types of stress, (i) Positive stress and (ii) Negative stress. Negative stress usually leads to unproductive mind and unwillingness towards work. Many organizations face these kinds of problems within, vice versa the positive stress leads to increasing productivity which can enhanced by using motivational technique. Motivation is an experience of desire or aversion (you want something or want to avoid or escape something). Motivation is a powerful, yet tricky beast. The author STEVEN PRESSFIELD has a great line in his book, "The war of art", "At some point, the pain of not doing it becomes greater than the pain of doing it". Some years ago BEHN et.al (1995) identified learning how to motivate employees and one of the "big" question of public management. Motivation is the desire to act in setting ant attaining one's objective- and this research shows that can influence their own levels of motivation and self-control. It is internally and externally both.
Motivation can have many sources, and often people have multiple motives for engaging in anyone behavior. Motivation might be intrinsic, whereby the inspiration comes from within a person- the desire to improve at a certain activity. Extrinsic motivation tends to push employees more forcefully. By American psychologist ABRAHAM MASLOW in 1943, humans are inherently motivated to better themselves and move towards expressing their full potential- selfactualization-by progressively encountering and satisfying several levels of need from the most fundamental, such as for food and safety, to higher order needs for love, belonging and self-esteem.

Employee motivation is the level of energy, commitment and creativity that a company's workers bring to their jobs. Whether the economy is growing or striking, finding ways to motivate employees is always a management concern. Competing theories stress either incentives or employee involvement (empowerment). Employee's motivation for increasing productivity to the success of an organization as motivated employees are generally more productive at the workplace. To achieve long term goal and success, an employer could use various technique or implement that encourages or inspire healthy competition between employees to achieve self and organizational target. At the conclusion of the program, the manager can announce the winner and give the reward for it.

If the employees are not satisfying at their workplace or continuously feeling stressful, it affects the ability and productivity of the employees. Stressful work usually responsible for stressful family life. The corporate job timings are more up to 12 hours a day, it means employees are living or spending daily time with colleagues more than the family members. If the minimum 10 hours a day going stressful, obviously the impact is worse than we think on their personnel life, the manager or an employer could use the various program and technique for motivating employees for increasing success, prosperity and satisfaction. 


\section{International Journal of Engineering Applied Sciences and Technology, 2020 Vol. 4, Issue 12, ISSN No. 2455-2143, Pages 163-169 \\ Published Online April 2020 in IJEAST (http://www.ijeast.com)}

\section{CONCEPT OF MOTIVATION}

The term motivation is derived from the word 'motive'. Motivation may be defined as a planned managerial process, which similar people to work to the best of their capabilities by providing them by motive, which are best on their unfulfilled needs. Work motivation is a set of energetic forces that originate both within as well as beyond an individual being, to initiate work related behavior, and to determine its form, direction intensity and duration. Understanding what motivate an organization's employee is central to the study of psychology.

Motivation can be concern as the desire to achieve same goal (Heyse and Hill, 2001) .It is observed that motivation is generally viewed as a process through which an individual need and desire are set in motion (Rakes and Donn, 2010). Furthermore, "motivation can be defined as everything that drives and sustain human behavior" (Gard, 2001). Additionally, "motivation is the process whereby goal-directed activity is

instigated and sustains" (Pintrich and Schunk, 1996). Above researcher try to define the motivation. In this era of competition, organization now a days are more emphasizing on the management of human resources (Robert. L. 2008). The following research shall attempt to clarify and enhance the technique for motivating employees for the success increasing productivity, work satisfaction and simultaneously satisfaction in personnel life.

\section{REVIEW OF LITERATURE}

Research on motivation has attracted academic and corporate entities over the last two decades. In the present study, authors have reviewed the intense literature to extract all possible dimensions of motivation, having direct and indirect impact on motivation techniques. This has examined the multidimensionality of motivation from the existing literature and present a conceptual framework based on it, and it is experienced that various motivation techniques (discussed in this study) are having a positive impact on both employee satisfaction and the quality of performance in the organization; however, the model needs to be validated using quantitative measures. In order to study the various issues highlighted in this paper related to employee motivation, a large body of literature mainly from different journals have been incorporated. To make the study more current only those studies were included which were published in the last two decades. In past research papers few dimensions of motivation were used to explain the different model's motivation theory which has direct influence on employee motivation. The novelty of this study lies in its theoretical framework where authors have made an attempt to come up with a construct having dimensions that directly or indirectly influences employee motivation.
In a complex and dynamic environment, leader of the organization used to create the environment in which employee feel trusted and are empowered to take decisions in the organization which leads to enhance motivation level of employee and ultimately organizational productivity are enhanced. Smith and Rupp (2003) stated that performance is a role of individual motivation; organizational strategy, and structure and resistance to change, is an empirical role relating motivation in the organization. Likewise, Luthans and Stankovic (1999) concluded that advancement of human resources through rewards, monetary incentives, and organizational behavior modification has generated a large volume of debate in the human resource and sales performance field. According to Orpen (1997) better the relationship between mentors and mentees in the formal mentoring program, the more mentees are motivated to work hard and committed to their organization. Likewise, Malina and Selto (2001) conducted a case study in one corporate setting by using balance score card (BSC) method and found out that organizational outcomes would be greater if employees are provided with positive motivation.

\section{MOTIVATION FOR INCREASING PRODUCTIVITY OF EMPLOYEES}

In before some decades the people or the employer didn't feel the necessity of motivation for the employees, but the world is of competition. If the people want to sustain in that, they should think innovative. The job of a manager is to get things done by employees, the management of people is an integral part of the management process (Tella et al., 2007). There are many theories and literature available for the motivation and now everyone can see the videos of it. In today's era the needs and demands of people growing day by day, so this kind of lifestyle leads to the mental stress. Following points disclose the research theory. These are beneficial to the managers to handle the employees and increase their performance. Chaudhry, AQ, \& Javed, H 2012, explained in his 'Impact of transactional and laissez faire leadership style on motivation', International Journal of Business and Social Science, Vol. 3, No. 7.Acknowledging a job well done makes employees feel good and encourages them to do good things. Employers recognize workers by tracking progress and providing feedback about how they have improved over time. Public recognition is also a motivating factor that drives worker productivity.

\section{1) Incentive-Based Motivation}

An incentive is a motivating influence that is designed to drive behavior and motivate employees to be produce quality work. Employers use several types of incentives to increase production numbers. Employee incentives come in a variety of forms including paid time off, bonuses, cash and travel perks.

Allowances are also considered being a very crucial factor to employee motivation. Many forms of allowances such cash 


\section{International Journal of Engineering Applied Sciences and Technology, 2020 Vol. 4, Issue 12, ISSN No. 2455-2143, Pages 163-169 \\ Published Online April 2020 in IJEAST (http://www.ijeast.com)}

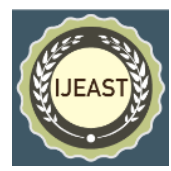

allowance, travel allowance, overtime allowance, and generally individual bonuses are all considered to be an important and significant factor to motivate and retain employees (Aamir et al, 2012). Armstrong (2008) proposed that the difference between allowance and pay is that allowance can be a pay for overtime or maybe adjustment towards increased cost of living, whereas the pay is the rate that could be hourly, monthly, or annually. Allowance can be considered under the benefits category, and DeNisi and Griffin (2008) claimed that most of the allowances can be classified under benefits which are designed for all employees with various levels of hierarchy. Allowances are a significant element of financial rewards for employee motivation as it boosts the employee's morale and also a feeling of belongingness as employees will live their lives with stability and dignity (Yousaf et al, 2014).

\section{2) Recognition and Rewards}

Many employees need recognition from their employers to produce quality work. Recognition and employee reward systems identify employees who perform their jobs well. Brown, Detal (2001), mentioned in his Reward Strategies; form intent to impact, London: CIPD. Some employers encourage fellow employees to issue \& quote; shout-outs \& quote; for good work. Moreover, perks like food and parties can also be a nice way to recognize good work.

\section{3) Self-Motivation and Confident Employees}

Some employees are motivated through feeling a sense of accomplishment and achievement for meeting personal and professional goals. Many workers are self-disciplined and selfmotivated.

Incentive and rewards have little effect on employees who feel motivated only when they are confident in their abilities and personally identify with their role within the organization. These individuals perform productively for the sake of the personal challenge work provides.

\section{4) Implementation Strategies}

There are several ways to motivate employees and drive worker productivity. Because different factors influence workers in different ways, utilize motivational strategies that encompass several techniques. For example, to influence workers who are money motivated, an employer may implement a daily \& quote; spiff \& quote; that pays cash instantly to employees who meet short-term production goals. To achieve long-term production goals, an employer could implement a program that encourages friendly competition between workers to meet production numbers.

But, through the process of implementation of above, the manager or the employer should mentor all the result or the backfired strategies. Motivational levels within the workplace have a direct impact on employee productivity. Workers who are motivated and excited about their jobs carry out their responsibilities to the best of their ability and production numbers increase as a result.

\section{THE IMPORTANCE OF MOTIVATION FOR PRODUCTIVITY}

An employee's motivation is a direct result of the sum of interactions with his or her manager."- Bob Nelson

Employee motivation is a critical aspect at the workplace which leads to the performance of the department and even the company. Motivating your employees needs to be a regular routine. There are several reasons why employee motivation is important. Mainly because it allows management to meet the company's goals. Without a motivated workplace, companies could be placed in a very risky position. Following benefits can increase the success ratio of the organization.

1) Satisfaction of needs:

Motivation helps in satisfying individual as well as group needs of employees. It results in the voluntary co-operation and co-ordination of employees and the goals of the organization can be easily achieved.

\section{2) Increased employee commitment}

When employees are motivated to work, they will generally put their best effort in the tasks that are assigned to them.

\section{3) Improved employee satisfaction}

Employee satisfaction is important for every company because this can lead towards a positive growth for the company. When employees are properly motivated, they use their skill and knowledge up to their maximum ability to show better results to the management. Nirav Dave et.al (2014) described in his research on the factors influencing job satisfaction of MBA faculty members in Gujarat state. International Journal of Advance Research in Computer Science and Management Studies, Volume 2, Issue 2, February 2014.

\section{4) Ongoing employee development}

Motivation can facilitate a worker reaching his/her personal goals and can facilitate the self- development of an individual. Once that worker meets some initial goals, they realize the clear link between effort and results, which will further motivate them to continue at a high level.

\section{5) Improved employee efficiency}

An employee's efficiency level is not only based on their abilities or qualifications. For the company to get the very best results, an employee needs to have a good balance between the ability to perform the task given and willingness to want to perform the task.

6) Productivity: 


\section{International Journal of Engineering Applied Sciences and Technology, 2020 Vol. 4, Issue 12, ISSN No. 2455-2143, Pages 163-169 \\ Published Online April 2020 in IJEAST (http://www.ijeast.com)}

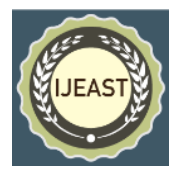

Motivation results in increased productivity since its basic object is to achieve the goals of the enterprise. The workers give their best performance which helps in increasing the productivity of the organization.

7) Reduction in labor turnover and absenteeism:

One of the most important contributions of motivation is that employees prefer to stay in the organization thereby reducing the labor turnover to the minimum. Similarly, motivated employees tend to be regular and the problem of absenteeism is also minimized.

\section{8) Acceptance of organizational changes:}

The technological changes taking place in this world have brought about revolutionary changes on the production side. Generally, employees resist these changes but with proper motivation they accept these changes, thereby keeping the organization in line with the other competing concerns.

9) Increase in all-round efficiency:

The friction among the workers and also between the management and workers is reduced to a great extent resulting in the all-round efficiency. It helps in decreasing the wastages, accidents, complaints and grievances.

\section{EXTERNAL/EXTRINSIC MOTIVATION AND INTERNAL/INTRINSIC MOTIVATION}

There two kinds of motivation mainly, there are two types of motivation, intrinsic motivation and extrinsic motivation (Thomas \& Velthouse, 1990, Mohsen et al., 2004, Gagne, 2005, Dwivedula et al., 2011, George and Sabapathy, 2011). Thomas \& Velthouse (1990), defined intrinsic motivation as "a positively valued experiences that an individual employee gets directly from their work tasks", stems from a direct relationship between the doer and the task (George and Sabapathy, 2011), depend on employee's volition to predict her behavior (Dwivedula et al., 2011). They are selfmotivated because they enjoy performing the actual tasks or enjoy the challenge of successfully completing the tasks (Mohsen et al., 2004). Intrinsic motivation describes all motivational- types driven by internal rewards while extrinsic motivation describes all motivational-types driven by external reward.

\section{I) External/ Extrinsic Motivation}

Extrinsic motivation represents all the things that motivate you based on external rewards like money or praise. These types of motivation are more common than intrinsic motivators and include achieving things due to a tangible incentive, fear, or expectation, all of which depend on external factors. For example, incentives and rewards, people work because of that.

\section{ii) Internal /Intrinsic Motivation}

Intrinsic motivation represents all the things that motivate you based on internal rewards like self improvement or helping a friend in need. For example, you may be motivated to get a promotion because you'll learn valuable skills. Conversely, you might be motivated to succeed because you want to positively affect the lives of the people around you. And some other types of motivation given bellow in short.

I) Competence \& amp; Learning Motivation. ...

II) Attitude Motivation. ...

III) Achievement Motivation. ...

IV) Creative Motivation. ...

V) Physiological Motivation. ...

\section{THEORIES REGARDING MOTIVATION IN WORKPLACE}

The many approaches to defining what drives human behavior is best understood. When considering the very purpose of creating them, be it increased performance, goal pursuit, resilience, or relapse prevention, to name a few.

There is nothing more practical than a good theory.

\section{-Kurt Lewin}

There is no single motivation theory that explains all aspects of human motivation, following some theories are popular and can explain need and the basis for the development of approaches and techniques to increase motivation in distinct areas of human endeavor.

\section{1) McClelland's achievement motivation theory}

McClelland took a different approach to conceptualize needs and argued that needs are developed and learned and focused his research away from satisfaction. He was also adamant that only one dominant motive can be present in our behavior at a time. McClelland categorized the needs or motives into achievement, affiliation, and power and saw them as being influenced by either internal drivers or extrinsic factors. The drive for achievement arises out of the psychological need for competence and is defined as a striving for excellence against a standard that can originate from three sources of competition: the task itself, the competition with the self, and the competition against others.

\section{2) Maslow's hierarchy of needs}

Abraham Maslow postulated that a person will be motivated when his needs are fulfilled. The need starts from the lowest level basic needs and keeps moving up as a lower level need is fulfilled. Below the figure 1 is the hierarchy of needs:

I. Physiological: Physical survival necessities such as food, water, and shelter.

II. Safety: Protection from threats, deprivation, and other dangers. 


\section{International Journal of Engineering Applied Sciences and Technology, 2020 \\ Vol. 4, Issue 12, ISSN No. 2455-2143, Pages 163-169 \\ Published Online April 2020 in IJEAST (http://www.ijeast.com)}

III. Social (belongingness and love): The need for association, affiliation, friendship, and so on.

IV. Self-esteem: The need for respect and recognition.

V. Self-actualization: The opportunity for personal development, learning, and fun/creative/challenging work. Self-actualization is the highest-level need to which a human being can aspire.

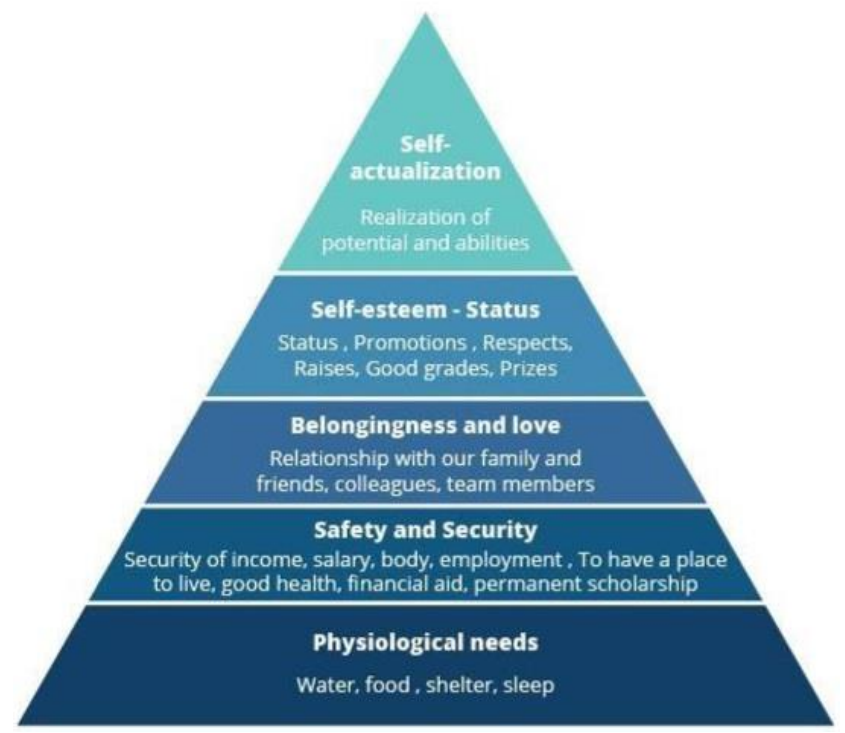

VI. The leader will have to understand the specific need of every individual in the team and accordingly work to help fulfill their needs.

\section{3) Hertzberg's two factor theory}

Hertzberg classified the needs into two broad categories namely hygiene factors and motivating factors.

\section{Hertzberg's Hygiene and Motivating Factors}

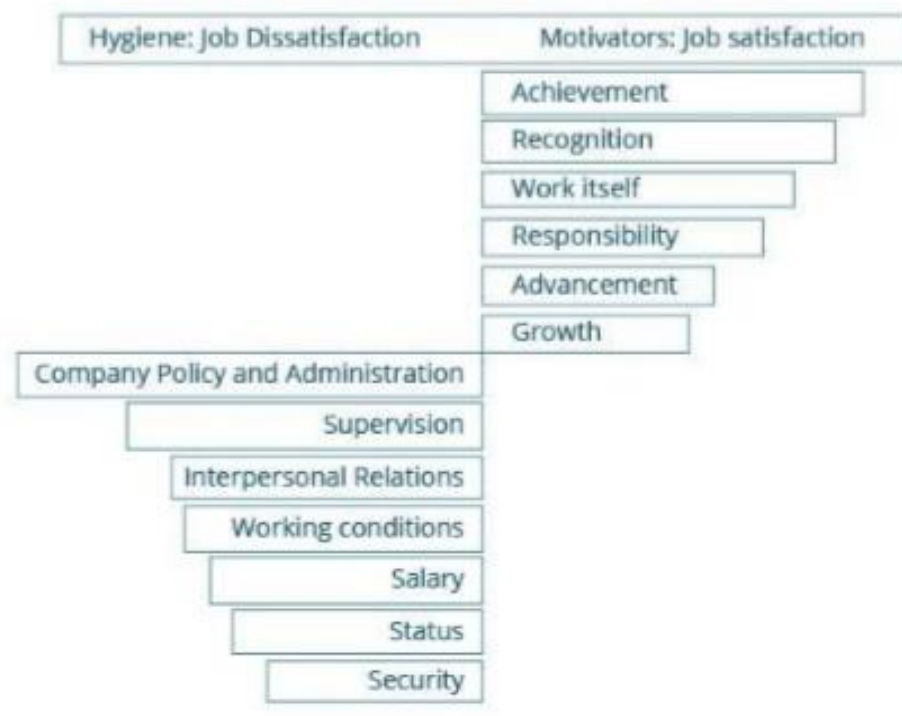

Hygiene factors are needed to make sure that an employee is not dissatisfied. Motivation factors are needed for ensuring employee\&\#39;s satisfaction and employee's motivation for higher performance. Mere presence of hygiene factors does not guarantee motivation, and presence of motivation factors in the absence of hygiene factors also does not work.

\section{4) Vroom's theory of expectancy}

Victor Vroom stated that people will be highly productive and motivated if two conditions are met: 1) people believe it is likely that their efforts will lead to successful results and 2) those people also believe they will be rewarded for their success.

People will be motivated to exert a high level of effort when they believe there are relationships between the efforts they put forth, the performance they achieve, and the outcomes/ rewards they receive.

\section{TECHNIQUES OF MOTIVATION}

The manager's main role is to balance the various activities of the organization. Among these, the most important activity is "getting work done through others". Following are main techniques of motivation for increasing productivity.

\section{1) Job Design}

Job design is also known as the 'Task' design or 'Work' design. It is one of the core functions of the HR management. Job design is defined as an arrangement or rearrangement of contents in a job to simplify duties and responsibilities. It decides the contents of the job and fixes the duties and responsibilities, methods of performing a job, the relationship among the managers, superiors, subordinates and peers.

\section{2) Job Enlargement}

Job enlargement is a job design technique in which, a variety of related tasks is associated to reduce the boredom and monotony. Here, a job is enlarged by horizontal restructuring method that is by adding various related tasks in order to facilitate workforce flexibility.

\section{3) Job Enrichment}

Job Enrichment is also called as Job Enhancement and it is a vertical restructuring technique. According to this technique employees are given an additional authority, freedom to take decisions to accomplish the job, autonomy, and control.

\section{4) Job Rotation}

This technique is used to make the employees expertise in performing various tasks. In job rotation employees are shifted between two or more jobs at regular time intervals in order to expose them to different experiences and to wider their skills. 


\section{International Journal of Engineering Applied Sciences and Technology, 2020 Vol. 4, Issue 12, ISSN No. 2455-2143, Pages 163-169 \\ Published Online April 2020 in IJEAST (http://www.ijeast.com)}

\section{5) Job Simplification}

It is a job design technique in which a job is broken into simple tasks to facilitate higher productivity and to reduce the mental or physical effort of the employees. Job simplification creates interest towards performing simple tasks.

\section{6) Rewards}

Employers use the rewards to motivate the employees and encourage them to reach the individual and organizational objectives.

\section{7) Employee participation:}

In employee participation, employees are empowered and are involved in decision-making. Once the employees are well informed, educated and trained regarding problemsolving then the managers may transfer decision-making authority to the employees. Quality of work life programs

Work life program represents maintaining a balance between family care, personal time and work. The wellness programs involve providing exercise facility, counselling regarding health, weight loss and smoking.

8) Quality of work life programs:

Work life program represents maintaining a balance between family care, personal time and work. The wellness programs involve providing exercise facility, counselling regarding health, weight loss and smoking.

\section{CONCLUSION}

In conclusion, Expectancy Theory is the root of all variances of motivation for employees in the workplace. What an employee expects from his or her employer is a direct relation to the employee's motivation for performance. Valiance, expectancy and instrumentality offer three different types of rewards for employees and depending on what type of reward is most important to the employee. Employees base their level of work and performance on the anticipation of how their employer will react. This is also true for students. If a student knows no matter how hard they study they know they will never receive an A then the motivation to study is less important. If a student knows the professor will recognize how hard they have worked then the motivation to study harder is greatly increased. Expectancy Theory applies to employees, students, parents, volunteers, etc. Everyone needs to be motivated to perform better whatever their current situation may be and this is directly related to what they expect to receive in return for their efforts. Nida Zafar et.al (2014) studies determinants of Employee Motivation and its impact on Knowledge Transfer and Job Satisfaction., International Journal of Human Resource Studies ISSN 21623058 2014, Vol. 4, No. 3.Here he has been explained the impact of motivation on employees.
It is observed that now a day there is a necessity of motivation. Mental health is as much important as physical health. To improve your mental health the motivation work better. Today the role of manager or a leader is not focused on one thing, the manager or an employer should inspire and motivate their employees for work by using above techniques. Job rotation and job enlargement and other techniques are good option to motivate. The organization can gain success and achieve profit simultaneously good position in market or business world. It is said that "good employees or good working mind is an asset to the company", the leader can create working mind or earn assets to the company motivation.

After all work satisfaction can lead to innovative working atmosphere in the organization. There are many examples of it like Facebook or TATA ,they satisfied their employees by incentives, good salary and showing them that the company cares for them by making their Bima or free hospital .From all these employees are attracted towards them and motivate to work with them.

\section{ACKNOWLEDGEMENT}

I would like to thank various people for their contribution to this project; Dr. G. V. Thakare, for their valuable suggestions and support; Dr. Ram Panchariya for his professional guidance, inspiring for this research. Special thanks should be given to Mr. Rishikesh Pihulkar for his valuable support and time.

\section{REFERENCES}

[1] Adeyinka Tella et.al (2007) Work Motivation, Job Satisfaction, and Organizational Commitment of Library Personnel in Academic and Research Libraries in Oyo State, Nigeria.

[2] Brown, D. (2001), Reward Strategies; form intent to impact, London: CIPD

[3] Aamir. A, Jehanzeb. K, Rasheed. A, Malik. O. M, 2012, Compensation Methods and Employees ${ }^{\text {ee }}$ Motivation (With Reference to Employees of National Commercial Bank Riyadh), International Journal of Human Resource Studies ISSN 2162-3058, Vol. 2, No. 3, pp. 221-230. [Accessed 27th May 2016].

[4] Aarabi. M. S, Subramaniam. I. D, Akeel. A. A. A, 2013, Relationship between Motivational Factors and Job Performance of Employees in Malaysian Service Industry, Asian Social Science; Vol. 9, No. 9; 2013 ISSN 1911-2017 E-ISSN 1911-2025. [Accessed 25th Jul 2016].

[5] Dwivedula, Ravikiran, \& Müller, R. (2011), Work Motivation as a Determinant of Organizational and Professional Commitment in Case of Temporary Organizations: Theoretical Perspectives, International Research Network for Organizing by Projects IRNOP 10, University of Quebec, Montreal, 1-27. 
[6] Gagne, M., \& Deci, E. L. (2005), Self-determination Theory and Work Motivation, Journal of Organizational Behavior, 26,331-362.

[7] George L., Sabapathy T. (2011), Work Motivation of Teachers: Relationship with Organizational Commitment.

[8] Nirav Dave et.al (2014) A research on the factors influencing job satisfaction of MBA faculty members in Gujarat state. International Journal of Advance Research in Computer Science and Management Studies, Volume 2, Issue 2, February 2014.

[9] Thomas, K. B., \& Velthouse, B. A. (1990), Cognition Elements of Empowerment: An "Interpretive" Model of Intrinsic Task Motivation, Academy of Management Review, 15, 666-681.

[10] Chaudhry, AQ, \& Javed, H 2012, 'Impact of transactional and laissez faire leadership style on motivation', International Journal of Business and Social Science, Vol. 3, No. 7.

[11] Nida Zafar et.al (2014) studies determinants of Employee Motivation and its impact on Knowledge Transfer and Job Satisfaction., International Journal of Human Resource Studies ISSN 2162-3058 2014, Vol. 4, No. 3

[12] BEHM, ROBERT D. 1995. The big question of public management. Public Administration Review 55: 313-24

[13] https://www.mindtools.com/pages/article/motivatingyour-team.h

[14] https://www.slideshare.net/mobile/ChRajkamal/employee -motivation-abstract

[15] https://smallbusiness.chron.com/motivation-productivityworkplace-10692.hand Work Motivation, Journal of Organizational Behaviour, 26,331-362. 